\title{
REVITALIZING THE ROLE OF MOTHERS AS CHILDREN'S FIRST SCHOOL
}

\author{
Chusna Apriyanti \\ English Education Study Program, STKIP PGRI Pacitan \\ chusna.apriyanti@gmail.com
}

\begin{abstract}
Abstrak
This study aims to determine the mothers' role in family life in Pacitan Regency, East Java and the ways to revitalize the mother's role. This is descriptive quantitative research. Data were collected by using a questionnaire of 74 women of childbearing age. This research was conducted in December 2020. In addition, the data were taken from interviews with respondents using a random sample technique. After being collected, the data is described in charts and conclusions drawn. The results showed that the mother has three main roles: fulfilling the children's needs, being a role model, and stimulating children's development. Criteria for fulfilling the children's needs is measured by indicators: mothers cook breakfast for children, pick up children from school, accompany children to play; 2) Mother as a role model for children; and 3) Mothers provide a stimulus to the children's development seen from the time accompanying their children to study, buy children story books and stationery, time to play gadgets.
\end{abstract}

Keywords: Career Woman, Double Role Mother, Mother's Role

\section{INTRODUCTION}

A career is no longer an obstacle for women to express their value, especially in Indonesia. Research conducted by Grant Thornton shows that more senior positions in companies worldwide are filled by women (Hanifia, C., \& Ratnaningsih, 2019). In Indonesia, the number of career women is increasing from last year. The growth of 16 percent from last year placed Indonesia in the top 10 countries of women in senior management positions in companies and was ranked sixth in the world. This has a big impact on the family. Women work not only for income but, like men, because of their desire for achievement and the satisfaction of using their skills and being recognized for it (Sutanto, 2000).

Most working women find it difficult to get a work-family balance because others suffer in one domain (Handayani et al., 2016). By having a lot of activities, working mothers will certainly reduce the mother's time with her family, especially time with her children. Their activities are various, ranging from formal and non-formal activities. In the end, mothers will delegate their duties to take care of the house and children to the babysitters and maids. This is normal and natural to see today. A tiring day's work, workloads that drain energy and mind, and various activities outside of work will make a mother have less ability to complete housework. The management of time between work outside the home and homework is not balanced. The effectiveness of the time given to educate children is also reduced because fatigue has drained their energy to think of effective and creative ways, so the time given is only leftover time. Data from various sources indicate that many women find it hard to achieve their desired combination of work and family time (Austen \& Birch, 2014).

The role of the mother in the family is not simple. The role of the mother is very dominant and noble. The position and function of the mother are fundamental because the mother is the first place for the formation of character for children (Widiani \& Jiyanto, 2018). Even the term "Indonesia strong from home" means that the Indonesian state will be strong if the family is strong. This is where the role of parents, fathers, and mothers can create a strong generation. According to Radhitya (2019), mothers have three main tasks: mothers who always provide for the needs of children, mothers as role models or "models" for imitating children, and mothers as stimulants for child development. Gwee (2009) states that the presence of mothers at home is considered very influential on the relationship and sense of security between 
mothers and children because this role will encourage children to learn actively for directed and optimal development results (Maulida, I. I. N., Makhfudli, \& Ulfiana, 2014)

Mothers have a role in providing for children's needs (Astarani \& Werdiningsih, 2012). This relates to the provision of physical and mental needs of children. Birth needs include the child's need for healthy and nutritious food, a comfortable place to live, etc. At the same time, the inner needs include the mother's presence in the child's important time, accompanying the child to play, and the emotional presence of the mother. Second, the role of mothers as role models for children is implemented in many activities. Mothers must set an example for their children to have good character. Parents must set an example. Studies have shown that early childhood is a period in which, developmentally, a child is learning a lot from their surroundings and the people around them (Lee, 2020). Third, the role of mothers in providing stimulus to children is related to the mother's efforts to educate qualified children. Educating children is related to meeting physical needs (eating, drinking, sleeping, clothing) and fulfilling inner needs such as creating strong children. Women's roles in life, especially a child's education, were significant; women have many functions, such as psychological development, education, and the development of social life (Erawati, 2016). It has been proved that in various family environments, children acquire various experiences through performing various activities and are constantly exposed to a range of influences and expectations from the people they cohabit (Ceka \& Murati, 2016).

Regarding family responsibilities, surely it is not only a problem for women with careers. Full-time women at home also have to return to their role as good mothers for children. There is no generalization that career women cannot take care of children and non-career women are more proficient. It all depends on the mother's perception and attitude. Thus, this study determines the mother's role in the family and explains strategies to play more roles in the family.

This research is urgently to be done because there are many cases related to the lack of mother's role in family matters. The case of double-role mothers, dozens of activities followed by mothers, low of time management are the reasons of this case. A lot of research discusses the role of mother, but most of them do not formulate the methods to formulate the revitalization of mother role. Most of the research are also use library research that do not find the data from the real subject.

\section{RESEARCH METHOD}

This study used a quantitative descriptive research design. Data were taken using a questionnaire to 74 women of productive age. The education level of the respondents was divided into five categories: did not finish elementary school (0\%), finished elementary school $(0 \%)$, completed junior high school $(0 \%)$, completed high school (8 people or $10.8 \%$ ), and undergraduate (66 people or $89,2 \%$ ). $91.9 \%$ of respondents are career women or have a business, and $8.1 \%$ do not have work outside the home. This research was conducted in December 2020. In addition to questionnaires, data were also taken from interviews with respondents using a random sample technique. Once collected, the data is described in a chart, and conclusions are drawn.

\section{FINDINGS AND DISCUSSION \\ Level of Mother's Role in the Family}

The mother's role is classified into 3 main roles, namely:

\section{Mother Meets Children's Needs}

The first role of the mother in the family is to meet the needs of the child, both physical and spiritual needs. The first indicator in meeting the needs of children is the intensity of mothers in providing breakfast for children. From the results of the study, the intensity of mothers in cooking breakfast for children is described in the following figure: 


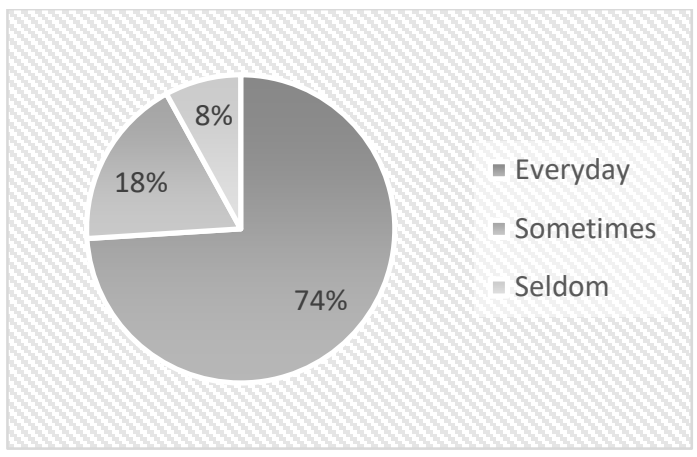

Figure 1:Mothers' Effort in Cooking Meals for Kids

In Figure 1, it is clear that the majority of mothers still cook breakfast for their children. A total of 55 respondents, or $74.3 \%$ of mothers, every day cook their children breakfast. The rest, 13 respondents or $17.5 \%$ of mothers, sometimes cook breakfast for their children. This is due to the busyness of mothers every morning who is struggling with other routines such as preparing children's schools and serving their husbands. Meanwhile, as many as 6 respondents, or $8.1 \%$, admitted that they rarely cook breakfast for children. Practicality is the main reason for this respondent.

The second indicator in meeting physical needs is picking up or dropping off a child's school. By picking up the child, the mother will communicate with the child on the way. The number of parents who pick up their children from school is illustrated in the following diagram:

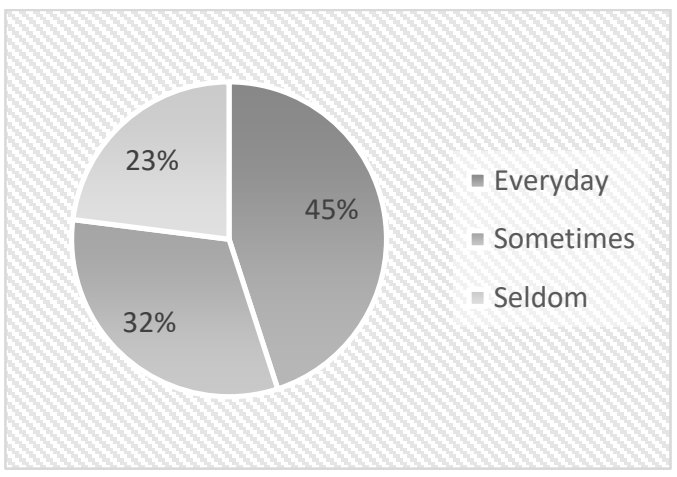

Figure 1: Intensity of Mothers Picking up Children from School

A total of 33 respondents, or $45.2 \%$ of parents, pick up their children from school every day. The rest, a total of 31.5 or 23 respondents, admitted that they sometimes pick up their children from school. They argue that sometimes they share tasks with their husbands in picking up children. Tragically, as many as 17 respondents, or $23.3 \%$ of mothers, never pick up their children from school. This is due to the busyness of the office and because there are already assistants in charge of serving the needs of the children.

The third indicator of meeting children's needs is related to the time spent playing with children. The number of parents playing with their children is described in the following figure: 


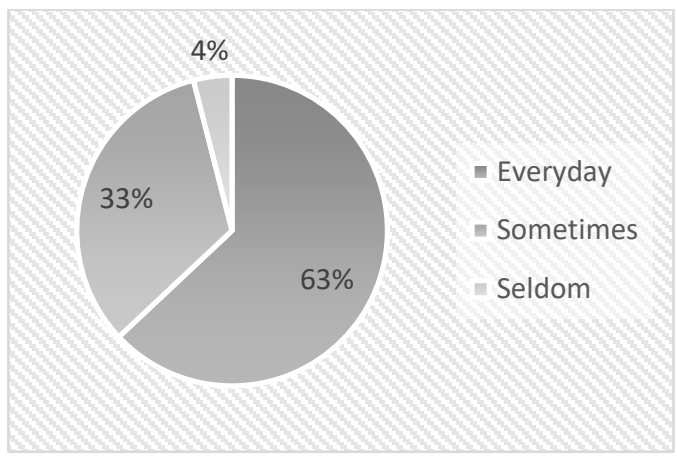

Figure 2: Mother's Time to Play with Children

Figure 3 explains that as many as 46 respondents, or $63 \%$ of mothers, admitted that they took time to play with their children every day. Although the duration is different. The rest, as many as 24 respondents or $32.9 \%$ of mothers, admitted that they sometimes play with their children, and tragically as many as 3 respondents do not have time at all in a week to play with their children. This is due to the extraordinary busyness of the mother. This study also stated that many mothers have many agendas outside the home besides work. The results are summarized in the following figure:

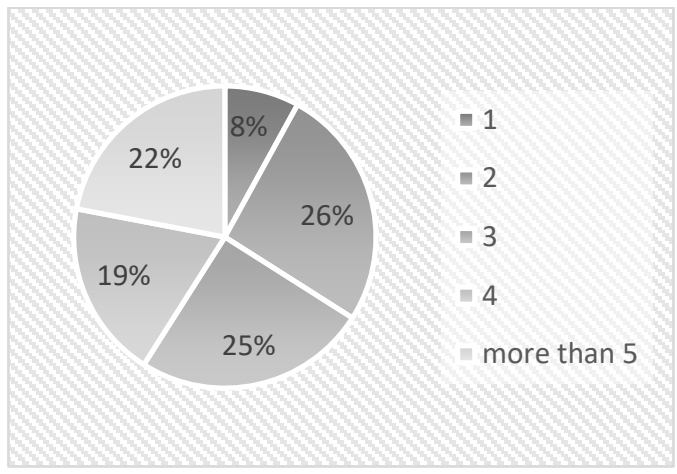

\section{Figure 3: Mother's Activities}

From Figure 4, it is clear that as many as 16 respondents or $21.9 \%$ of mothers have activities outside of work 5 or more times a week. The activities in question consist of social gatherings and other activities. It can be imagined how much time is left for children outside of work; mothers have activities outside the home more than 5 times a week. The rest, as many as 14 respondents or $19.2 \%$ have 4 outside activities, 18 respondents or $24.7 \%$ have 3 outside activities, 19 respondents or $26 \%$ have 2 activities, and only 6 respondents or $8.2 \%$ have only one activity outside the home other than work.

\section{Mother as a Child's Role Model}

In addition to meeting the needs of children, mothers must also be good role models for children. Mothers who set a good example are expected to educate children with good character as well. This, of course, requires awareness from the mother to be a good example for children. Doing daily tasks such as washing clothes and making bed also have a good impact on children. Children who see their parents can make the bed after waking up will imitate children in the future.

\section{Mother Provides Stimulus for Children Development}

In the development, sometimes there is a misperception of the child's growth and development. Many parents emphasize that children's education is the teacher's job. However, 
to comply with the integrated support system for their students, schools need to build a partnership with parents and develop mutual responsibility for children' success in the educational system (Đurišić \& Bunijevac, 2017). The teachers cannot solely educate children at school. Parental involvement has always been an essential component of every teacher-student school academic endeavour (Sapungan \& Sapungan, 2014).

There is a term that the mother is the first school for the child. The results showed that not all mothers had sufficient time to accompany their children to study, as shown in the following figure:

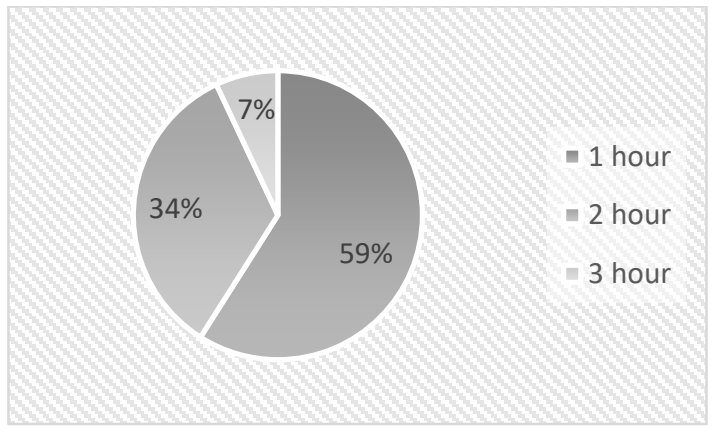

\section{Figure 4: Mother's Time in Accompanying Children to Study}

Figure 5 shows that 5 respondents, or $7.1 \%$ of mothers, accompany their children to study for 3 hours. The rest, as many as 24 respondents or $34.3 \%$ mothers, accompany their children for 2 hours, and the remaining 41 people, or $58.6 \%$, accompany their children to study for 1 hour. Some mothers only check their children's assignments without any feedback, which is more often than children falling into the 1-hour category. They claim to use private tutoring services and tutoring outside of school to support their children's achievements at school.

But the encouraging thing is seen from the mother's willingness to stimulate the child's development. As many as $97.3 \%$ of mothers admitted buying books and stationery for their children even though they had not yet entered school age. Meanwhile, the remaining $2.7 \%$ admitted that they did not buy reading books or stationery before their children entered school. This needs to be given a deep understanding that stimulating children's development must be done since a newborn child (Ariyani, 2016). The golden age is a golden era for children to learn. Do not let gadgets replace the role of mothers as the first school for children. The results showed that mothers were still ignorant of their children's playing time on gadgets. The full details can be seen in the following image:

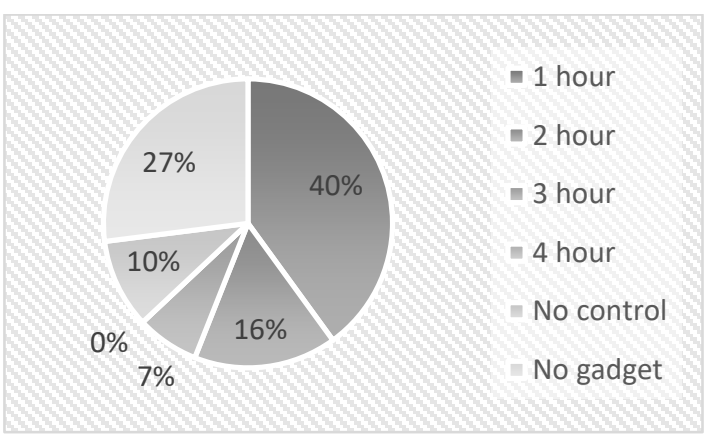

\section{Figure 5: Gadget Time}

From Figure 6, as many as 20 mothers or $27.4 \%$ of respondents do not allow their children to play with their gadgets at home. The rest, a total of 29 mothers or $39.7 \%$ of mothers, allow their children to play with their gadgets for 1 hour a day, 12 mothers or $16.4 \%$ of 
respondents allow their children to play with their gadgets for 2 hours, 5 respondents or $6.8 \%$ of mothers allow their children to play their gadgets for 3 hours. But tragically, 7 mothers or $9.6 \%$ of respondents freed their children to play with gadgets. They do not control the time their children play with their gadgets, and they only remind them to bathe, eat, sleep, etc.

Gadget itself has two sides. One effect of gadget usage on children is self-isolated from social life and lack of emotional management (Suhana, 2018). As the solution, parents could additionally provide toys and alternative games suitable for the children's age, developmental ability, and safety needs (Ardiyani et al., 2021). On the other sides, gadget can give benefits for children when they use it as tools for learning. They can search materials related to their subject learned by joining to e-courses or joining the digital classes provided. They also can use YouTube as the sources of learning. There are a lot of videos related to their subjects. Research concludes that children who use high gadgets with low parental involvement in their prosocial behaviour levels are lower than children who use low gadgets with parental involvement (Laini, 2018).

\section{Ways to Revitalize the Mothers' Role as the First School for Children}

From the data results above, it is necessary to change perceptions to return mothers to their main role as the first school for children. The steps that can be taken are as follows:

1. Be a listener as well as a friend for children (Ratnasari, 2007). Ways that can be done include participating in parenting socialization and child psychology. A mother will be able to help overcome her child's problems when she knows the interests and talents and the psychological condition of her child.

2. Make effective use of family time. One way that can be done is not spending a lot of time at home playing gadgets, paying attention and inviting children to play, and taking time to go out together.

3. Manage finances well. A mother must manage her finances by buying things that are needed and not consumptive.

4. Do not burden all household matters to the maid. A mother should be more familiar with the ins and outs of her own home by organizing and being responsible for home activities.

5. Be a role model for children by giving good examples in terms of attitude and words. This will make the child not feel pressured when advised and make the mother become an idolized figure.

6. Instil mutual respect between family members, that there are responsibilities of each that must be completed.

\section{CONCLUSION}

The effectiveness of a mother's time with her child is very important. The results of the mini-research through online questionnaires show that there are still many mothers who have not maximized their role in the family. Simple things such as taking children to school or cooking children's breakfast cannot be handled properly by a mother. In fact, out of 74 respondents, 3 mothers admitted that they never played with their children. This is very unfortunate considering that mothers have three main roles for children: meeting physical and spiritual needs, being a role model for children, and stimulating child development.

\section{REFERENCES}

Ardiyani, I. D., Setiawati, Y., \& Hsieh, Y.-T. (2021). EDUCATION FOR PARENTS OF CHILDREN WITH GADGET ADDICTION. 9(3), 221-230. https://doi.org /10.20473/ jbe.v9 i32021.221 
Ariyani, T. (2016). PENTINGNYA PENDIDIKAN ANAK USIA DINI BAGI TUMBUH KEMBANG ANAK. JURNAL DINAMIKA PENDIDIKAN DASAR VOLUME 8, NO 1, Maret $2016: 50-58$.

Astarani, K., \& Werdiningsih, A. (2012). Role in Meeting the Needs of Mother on Child Development Preschoolers. Jurnal Penelitian STIKES Kediri, 5(1), 82-98-98.

Austen, S., \& Birch, E. (2014). Family Responsibilities and Women's Working Lives Family Responsibilities and Women's Working Lives by Women's Economic Policy Analysis Unit Curtin University of Technology. Women's Economic Policy Analysis Unit (WEPAU), January 2002.

Ceka, A., \& Murati, R. (2016). the Role of the Parents in the Education of Children. Psychiatry and Clinical Neurosciences, 6(3), 221-230. https://doi.org/10.1111/j.14401819.1952.tb01331.x

Đurišić, M., \& Bunijevac, M. (2017). Parental involvement as a important factor for successful education. Center for Educational Policy Studies Journal, 7(3), 137-153.

Erawati, D. (2016). Public Perception of the Mother' s Role in Children' s Education ( Sociological Study of Kahayan Riverside Society InPalangka Raya City of Central Kalimantan ). IOSR Journal of Research \& Method in Education, 6(6), 49-54. https://doi.org/10.9790/7388-0606024954

Handayani, A., Afiatin, T., M.G. Adiyanti, \& Fathul Himam. (2016). Psychosocial Factors Influencing Work - Family Balance of Working Mothers. Researchers World : Journal of Arts, Science and Commerce, VII(4(1)), 33-43. https://doi.org/10.18843/rwjasc/v7i4(1)/04

Hanifia, C., \& Ratnaningsih, I. Z. (2019). HUBUNGAN ANTARA PERSEPSI DUKUNGAN ORGANISASI DENGAN KESEIMBANGAN KERJA-KELUARGA PADA DOSEN WANITA DI UNIVERSITAS DIPONEGORO. Fakultas Psikologi, Universitas Diponegoro, 002.

Harahap, Risma Delima (2017). Pelaksanaan Pembelajaran Sains Biologi dan Pengaruhnya Terhadap Prestasi Belajar Siswa di SMA Swasta Muhammadiyah 09 Kualuh Hulu Labuhanbatu Utara. Jurnal Pembelajaran dan Biologi Nukleus Vol. 3 No. 2

Harahap, Risma Delima (2018). Kepemimpinan Kepala Sekolah Dalam Meningkatkan Motivasi Mengajar Guru DI SMP N2 Sigambal. Jurnal Eduscience. Vol.5 No. 1

Laini, A. (2018). Influence of Gadget Usage and Parent Involvement To Children'S Prosocial Behavior. Jurnal Imiah Pendidikan Dan Pembelajaran, 2(2), 174-179. https://doi.org/10.23887/jipp.v2i2.15366

Lee, C. M. (2020). A Mother's role in early childhood development. Healthway Medical.

Maulida, I. I. N., Makhfudli, \& Ulfiana, E. (2014). PERBEDAAN PERAN IBU DALAM STIMULASI PERKEMBANGAN ANAK USIA PRASEKOLAH PADA IBU BEKERJA DAN TIDAK BEKERJA DI WILAYAH KERJA PUSKESMAS BANYU URIP SURABAYA. Ndonesian Journal of Community Health Nursing.

Radhitya, T. V. (2019). Peran Ganda Yang Dialami Pekerja Wanita K3L Universitas Padjadjaran. Focus : Jurnal Pekerjaan Sosial, 1(3), 204. Https://Doi.Org/10.24198/Focus.V1i3.20497. 
Ratnasari, A. (2007). Komunikasi Harmonis Orang Tua dengan Anak. Mediator: Jurnal Komunikasi, 8(2), 345-352. Https://Doi.Org/10.29313/Mediator.V8i2.1247.

Sapungan, G. M., \& Sapungan, R. M. (2014). Parental Involvement in Child's Education: Importan ce, Barriers and Benefits. Asian Journal of Management Sciences $\mathcal{E}$ Education Vol. 3(2) April 2014, 3(April), 42-48.

Suhana, M. (2018). Influence of Gadget Usage on Children's Social-Emotional Development. 169(Icece 2017), 224-227. https://doi.org/10.2991/icece-17.2018.58

Sutanto, E. M. (2000). Working Women and Family. Journal of the American Medical Women's Association (1972), 55(2), 76-79. http://europepmc.org/article/med/10808656

Widiani, D., \& Jiyanto, J. (2018). the Importance of Mother'S Role in Preventing Children'S Radicalism. YINYANG: Jurnal Studi Islam, Gender Dan Anak, 13(1), 33-69. https://doi.org/10.24090/yinyang.v13i1.2018.pp33-69 